\title{
Promising Leuce poplar clones in sandy ridges between the rivers Danube and Tisza in Hungary: a case study
}

\author{
${ }^{1 *}$ Károly Rédei $-{ }^{3}$ Marianna Takács $-{ }^{2}$ Tamás Kiss $-{ }^{2}$ Zsolt Keserú \\ ${ }^{1}$ University of Debrecen Faulty of Agricultural and Food Sciences and Environmental Management, Debrecen \\ ${ }^{2}$ National Agricultural and Innovation Centre- Forest Research Institute, Deparment of Plantation Forestry, Püspökladány, Hungary \\ ${ }^{3}$ University of Debrecen Faulty of Agricultural and Food Sciences and Environmental Management, Department of Animal Science, \\ Debrecen \\ *redei.karoly@gmail.com
}

\begin{abstract}
SUMMARY
An intensive integrated research and development work has been carried out on the improvement of Leuce poplars including primarily the native white poplar (Populus alba L.) and its natural hybrid grey poplar (Populus $\times$ canescens). More than 70 percent of the Leuce poplar stands can be found on calcareous sandy sites in the Danube-Tisza region, so they play a significant role in the poplar management of this part of the country. The most important task ahead of Hungarian poplar growers is to improve the quality of poplar stands and plantations based on selecting new clones and cultivars. The growth and yield of four promising Leuce poplar clones was evaluated on a marginal site in central Hungary. The clones 'H 425-4' (Populus alba L. × Populus alba L.), and 'H 758' (Populus alba L. Mosonmagyaróvár 124) seem to be suitable for wood production, while the 'H 427-3' (Populus alba L. $\times$ Populus alba L. cv. Bolleana) and 'H 422-9' (Populus alba L. $\times$ Populus grandidentata (Michx)) clones (with decorative stem form) could be better used for tree lines and ornamental plantations.
\end{abstract}

Keywords: Leuce poplars, clonal selection, experimental plantations

\section{INTRODUCTION}

White poplar (Populus alba L.) and its most important natural hybrid, the grey poplar (Populus $\times$ canescens (Aiton) Sm.) are native poplar species in Hungary. The area of poplar stands and plantations in the country was approximately 112 thousand ha in 2016 (5.5 per cent of the total forested land) (NÉBIH, 2016).

More than $70 \%$ of the white poplar stands can be found on calcareous sandy sites on the Danube-Tisza region. About $35 \%$ of the new afforestation and artificial regenerations is carried out presently with Leuce poplars in the mentioned region. They have a rich gene pool on the sand dune region in the middle of the Great Hungarian Plain and on the bottomland of big rivers. In the future, due to the establishment of national parks in these regions, considerable increases can also be expected in the field of native poplars management. At the same time their importance will be increasing in the large areas of marginal sites which are not suitable for hybrid poplars but can accommodate native ones.

In the Danube-Tisza region some very important ecological factors have become unfavourable for poplar growing in the last two decades. There is no sufficient precipitation during the growing season (appr. 250-300 $\mathrm{mm}$ ), and the rivers' control and canalisation have caused a drastic lowering of the ground-water table in many places. In such spots the water supply for poplars depends on the moisture content of soils, accumulating waters on the surface and on the water-storing capacity of soils. Therefore, the main aim of the selection work is to find and improve Leuce poplar clones and cultivars that have good shape, provide good-quality wood material for industrial purposes (without false heartwood), and that can adapt to the global climate changed conditions (Rédei, 1991, 1999, 2000).

\section{BRIEF SUMMARY ON BREEDING AND IMPROVEMENT OF POPLARS IN HUNGARY}

The basis for the breeding and improvement programme was a series of clones given in the frame of co-operation, during the 1950's by the Poplar Research Institute of Italy, Belgium, the Netherlands, France, Germany and Yugoslavia, combined with the genetic heritance of Hungarian forests (Populus nigra L. and Populus alba L.). This research programme was started by the prominent scientists of the Hungarian Forest Research Institute (FRI), Gy. Koltay and F. Kopecky. In Hungary FRI (at present NARIC-FRI) is the most important national institution for poplar breeding and improvement. It took part in provenance testing experiments of Populus trichocarpa (Torr. \& A. Gray ex. Hook), Populus deltoides (W. Bartram ex Marshall) and Populus nigra L., which were launched by FAO and IUFRO. Due to breeding activities over four decades, about 80000 seedlings were produced and tested by FRI, of which $50 \%$ were among interspecific and intraspecific hybrids of the Aigeiros section, $15 \%$ of the Leuce section and $35 \%$ of the Tacamahaca section (Kopecky, 1962, Tóth,1996).

The number of clones selected out of progenies amounts to more than 1000 . These clones, screened by early testing methods, make up a considerable part of the collection of FRI and at the same time primary materials for clonal testing experiments. This poplar cross-breeding resulted in several excellently growing euramerican poplar clones, of which Populus $\times$ euramericana (Moench) 'Pannonia', 'Kopecky' and 'Koltay' have been admitted to the official national poplar clone-choice and are integral parts of the state approved and tested varieties. 
Selection breeding was mostly directed to native poplars (Kopecky, 1962, 1978). According to his research on native poplar hybrids, the $P$. alba $L . x P$. grandidentata (Michx) ' $H$ 422-1', the ' $H$ 422-6', the $P$. alba L. $x$ P. alba L. 'H 425-4' and the 'H 325-10' clones could have some growing-importance. The $P$. alba $L$. cv. 'Bolleana' ' $H$ 427-3', the $P$. alba $L . \times P$. grandidentata (Michx) ' $H$ 422-1' and the ' $H$ 422-6' clones can be planted in roadside plantations and parks for their decorative value on the whole range of suitable sites. On the calcareous sites of the Great Plain only the P. alba L. cv. 'Bolleana', the 'H 372-1' and the 'H 3722' can be planted.

Selection investigations on marked individuals and populations of native poplars laid the foundation for their possible in situ and ex situ conservation (Keserü et al., 2005). Marked gene-reserves extend to roughly 100 ha and the number of registered plus-trees is about 200 (in situ gene preservation). In Hungary the area of native and hybrid poplar experiments amounts to 400 ha. Geographically they are dispersed in the poplar growing regions, and therefore are suitable for drawing conclusions on clone-site relations under the typical conditions of the country.

\section{METHODS}

Suitable observation techniques make it possible to observe some characteristics important for breeding already at an early stage of development of trees, while other characteristics are manifested at a later age. The responses of clones under different environmental conditions is a result of their greater or smaller adaptability in regard to survival, rate of growth, resistance to damages, etc.

\section{Description of study area}

In the past 20 years the Hungarian Forest Research Institute established several comparative trials with Leuce poplar clones for investigating their site requirements, growing patterns and yield. The trial discussed in this paper was allocated in subcomparment Szentkirály $40 \mathrm{G}$ in the Danube-Tisza interflow region (Figure 1) in spring 1988, with the following clones:

- 'H 427-3' (Populus alba L. × Populus alba L. cv. Bolleana),

- 'H 758' (Populus alba L. Mosonmagyaróvár 124),

- 'H 425-4' (Populus alba L. × Populus alba L.),

$$
\mathrm{v}=\mathrm{d}^{2 *}\left(\mathrm{~h}^{(\mathrm{po}+1)}\right) *\left(\mathrm{p}_{1} * \mathrm{~d} * \mathrm{~h}+\mathrm{p}_{2} * \mathrm{~d}+\mathrm{p}_{3} * \mathrm{~h}+\mathrm{p}_{4}\right) /\left(\left((\mathrm{h}-1.3)^{\mathrm{po}}\right) * 10^{8}\right)
$$

where $d$ is diameter at breast height $\left(d_{1.3}, c m\right)$, h is tree height $(m), p_{0}=2, p_{1}=-4236, p_{2}=12.43, p_{3}=4.6, p_{4}=3298$.

Then we can calculate the total volume per ha $(\mathrm{V})$ :

$$
\mathrm{V}=\mathrm{v} * \mathrm{~N} \text {, where } \mathrm{N}=\text { stem number per ha. }
$$

\section{Tree quality classification}

To characterize tree quality, the stem quality index at the age of 20 was defined, by using the following stem quality classes: Class 1 - The stem is straight, cylindrical, healthy and reaching the top of the crown. Class 2 - The stem is straight and healthy, forks are tolerated, but only if they are in the uppermost third of the tree. Class 3 - The stem is crooked, leaning and 
more or less damaged. Class 4 - The stem is very crooked in more than one dimension and heavy damaged. The stem quality index was calculated as the average of the stem classes weighted by stem number.

The statistical analyses were carried out ANOVA Program (STATISTICA 8.0 data analysis software system - StatSoft, Inc. 2008).

\section{RESULTS}

Some yield data and the relevant percentage-values compared to the control calculated on the basis of replications' means at the age of 20 can be found in Table 1.

On the basis of the data, considering the growth in height, and dbh the clone ' $H$ 425-4' provided the best result. It overpassed the control by 6 and 4 per cent, respectively. The tendency is the same with regard to the mean tree volume values. The effect of differences in dbh. on the mean tree values seems to be considerable (additional 8 per cent for the abovementioned clone). As the tree quality index is concerned, the succession from best to worst is: ' $H 425$ 4', 'H 758' ' $H$ 427-3' and ' $H$ 422-9'.

According to the significance test at $\mathrm{P}=5 \%$ level, significant differences were found in $\mathrm{dbh}\left(\mathrm{SD}_{5 \%}=7 \mathrm{~cm}\right)$ and in the mean tree volume values $\left(\mathrm{SD}_{5 \%}=0.144 \mathrm{~m}^{3}\right)$.

The trees in the clone trial, as it was mentioned above, thrive under marginal site conditions that are normally unfavourable for poplar growing. Considering this fact, the early evaluation showed that all the examined Leuce poplar clones are promising for growing on the above-described sites. The clones ' $H$ 425-4' and ' $H$ 758' seem to be suitable for wood production, while the ' $H$ 427-3' and ' $H$ 422-9' ones (with decorative stem form) could be better used for tree lines and ornamental plantations. The clone marked ' $H$ 425-4' has been registered as cultivarcandidate.

Yield data of white poplar clones at the age of 20 (replications' means)

\begin{tabular}{lcccccc}
\hline $\begin{array}{c}\text { Name of } \\
\text { clones }\end{array}$ & $\begin{array}{c}\text { Mean height } \\
\mathrm{m}\end{array}$ & $(\%)$ & $\begin{array}{c}\text { Mean dbh } \\
\mathrm{cm}\end{array}$ & $(\%)$ & $\begin{array}{c}\text { Mean tree volume } \\
\mathrm{m}^{3}\end{array}$ & $\begin{array}{c}(\%) \\
\text { Stern quality } \\
\text { index }\end{array}$ \\
\hline & & & & & & \\
'H 427-3' & 19.6 & 92 & 18.1 & 74 & 0.259 & 52 \\
'H 758' & 20.3 & 95 & 22.2 & 99 & 0.402 & 80 \\
'H 425-4' & 22.6 & 106 & 25.6 & 104 & 0.542 & 1.6 \\
'H 422-9' & 18.8 & 88 & 17.9 & 73 & 0.244 & 49 \\
Control* & 21.4 & 100 & 24.5 & 100 & 0.501 & 1.5 \\
\end{tabular}

* data derived from yield table (Rédei, 1991)

\section{CONCLUSIONS}

The selected Leuce poplar clones have to fulfil the following criteria (Mátyás, 1983): intensive early growth to outcome cultivation stage as far as possible; straight stem to keep mechanical processing; fine branching; good rooted ability; variable felling age, to enable us to prolongation the rotation age; coarse bark (increases tolerance against game damage), and differences among clones in the phenology of bud burst which helps to prolong the planting period. As the results suggest, systematic testing is essential in poplar breeding. However, results with smaller probability of error can only be achieved after a long period of research. The systematic evaluations of clone trials set up in the past decades in Hungary will make it possible to select Leuce poplar clones more reliably which can meet all the requirements drafted in the introduction to this paper.

\section{REFERENCES}

Keserú, Zs.-Balla, I.-Antal, B.- Rédei, K. (2015) Microporopagation of Leuce poplars and evaluation of their development under sandy site conditions in Hungary. Acta Silvatica and Lignaria Hungarica. Vol. 11, No. 2: 139-152

Kopecky, F. (1962): Poplar breeding. In Keresztesi, B. (edit.): Poplar growing in Hungary. Mezõgazdasági Kiadó. Budapest, 83-117.

Kopecky, F. (1978): Cross-breeding. In Keresztesi, B. (edit.): Poplar and willow growing. Mezõgazdasági Kiadó. Budapest, 47-65.

Mátyás, Cs. (1983): An Intorduction to Forest Tree Improvement. Sopron University Multipliers. pp. 175.

NÉBIH (2016): Erdővagyon és erdőgazdálkodás Magyarországon 2016-ban (in Hungarian). Budapest
Rédei, K. (1991): Improvement of Leuce-poplars growing in Hungary. Erdészeti Kutatások. 82-83:304-312.

Rédei, K. (1999): Promising White Poplar (Populus alba L.) clones in Sandy ridges Between the Rivers Danube and Tisza in Hungary. Hungarian Agricultural Research. 8. 3:4-8.

Rédei, K. (2000): Early performance of promiting white poplar (Populus alba L.) clones in sandy ridges between the rivers Danube and Tisza in Hungary. Forestry, Vol. 73, No. 4: 407-413. Sopp, L. edit. (1974): Volume tables. Mezõgazdasági Kiadó. Budapest, 170-175.

Tóth, B. (1996): Poplar and willow growing in Hungary. FRI, Budapest, 4-56. 
